Rev. Latinoam. Psicopat. Fund., São Paulo, v. 14, n. 2, p. 362-366, junho 2011

\title{
A Serra da Piedade e a Irmã Germana (1833)'
}

Auguste de Saint-Hilaire

Conheci na Serra da Piedade uma mulher de quem falavam muito nas comarcas de Sabará e Vila Rica. A irmã Germana, tal o seu nome, fora atacada dez anos antes (escrito em 1818), de afecções histéricas acompanhadas de convulsões violentas. Fizeram-na exorcismar; empregaram-na remédios inteiramente contrários ao seu estado e o mal agravou-se. Ao tempo de minha viagem ela chegara, havia já muito tempo, ao ponto de não poder mais deixar o leito, e a quantidade de alimentos que ela tomava cada dia era pouco maior que a que se dá a um recém-nascido. Ela não comia carne e recusava igualmente as gorduras, não podendo mesmo tomar um caldo. Alguns doces, queijo, um pouco de pão ou farinha, constituíam

1. O relato encontra-se em capítulo intitulado "Partida de Itajurú. A cidade de Caeté. A Serra da Piedade e a Irmã Germana". Transcrito de Saint-Hilaire, Auguste. Viagens pelo distrito dos diamantes e litoral do Brasil: com um "Resumo histórico das revoluções do Brasil, da chegada de d. João VI à América à abdicação de D. Pedro”. Tradução Leonam de Azeredo Pena. São Paulo: Companhia Editora Nacional, 1941, p. 117-123. Na edição francesa de 1833, o trecho se encontra no volume 1, p. 142-149 (Voyage dans le district des diamans et sur le littoral du Brésil. Paris: Gide, 1833). (Nota da editora). 
todo o seu alimento; frequentemente recusava alimentar-se e quase sempre era preciso obrigá-la a comer qualquer cousa.

Era voz geral que os costumes de Germana haviam sido sempre puros e sua conduta irrepreensível. Durante o curso de sua moléstia, sua devoção crescia dia a dia: queria jejuar completamente às sextas e sábados; a princípio sua mãe quis impedi-la, mas Germana declarou que durante esses dois dias era-lhe inteiramente impossível tomar qualquer alimento e daí por diante ela passou-os sempre na mais completa abstinência.

Para satisfazer sua devoção pela Virgem ela se fez transportar à Serra da Piedade, cuja capela fora erguida sob a invocação de Nossa Senhora da Piedade, e obteve permissão de morar nesse asilo. Lá, meditando um dia sobre os mistérios da Paixão, entrou em uma espécie de êxtase; seus braços endureceram e estenderam-se em forma de cruz; seus pés cruzaram-se igualmente e ela se manteve nessa atitude durante 48 horas. À época de minha viagem havia quatro anos que esse fenômeno se dera pela primeira vez e daí por diante ele se repetira semanalmente. A irmã Germana tomava essa atitude extática na noite de quinta para sexta-feira, conservando-se assim até a noite de sábado para domingo, sem fazer um movimento, sem proferir uma palavra, sem tomar qualquer alimento.

Os rumores desse fenômeno espalharam-se logo pelos arredores; milhares de pessoas, de todas as classes, testemunharam-no; acreditou-se no milagre; a irmã Germana foi proclamada santa, e dois cirurgiões dos arredores aumentaram ainda a veneração pública, declarando por escrito que o estado da doente era sobrenatural. Essa declaração ficou manuscrita, mas circulou de mão em mão, sendo dela tirado um grande número de cópias. Entretanto, um médico muito culto, o dr. Gomide, da Universidade de Edimburgo, achou-se no dever de refutar a declaração dos dois cirurgiões e, em 1814, fez imprimir no Rio de Janeiro, sem o nome do autor, uma pequena brochura, cheia de ciência de lógica, onde prova, com uma multidão de autoridades, que os êxtases de Germana não eram senão o resultado de uma catalepsia.*

* A brochura de que se trata intitula-se: Impugnação Analítica ao exame feito pelos clínicos Antônio Pedro de Sousa e Manuel Quintão da Silva em uma rapariga que julgaram santa na capela da Senhora da Piedade da Serra, etc., Rio de Janeiro. Nesse trabalho o dr. Gomide, procurando explicar a periodicidade dos êxtases de Germana, conta o fato seguinte, que a meu ver merece ser relembrado: "Um proprietário dos arredores de Caeté possuía uma tropa de mulas que empregava no transporte, aos sábados, de víveres à vila. Cada dia esses animais, deixados, segundo o costume, no pasto, vinham pela manhã e à tarde procurar em casa de seu dono sua costumeira ração de milho. Mas aos sábados, único dia de trabalho, não somente eles não se apresentavam para a ração, como ainda, escondiam-se no campo. (Nota de Saint-Hilaire) 
A opinião do público dividiu-se, mas uma multidão de pessoas continuou a subir ao alto da Serra para admirar o prodígio de que ela era teatro. Entretanto, o último bispo de Mariana, o padre Cipriano da Santíssima Trindade, que era um homem ajuizado e competente, compreendeu a inconveniência das numerosas reuniões provocadas pela presença de Germana na Serra da Piedade e, para diminuir o pretenso milagre, proibiu a celebração de missas na montanha, sob o pretexto de que o Rei não havia dado permissão. Várias pessoas ofereceram a Germana abrigo em suas casas; ela preferiu o seu diretor, homem grave, de idade avançada, que residia nas vizinhanças da montanha. Os devotos ficaram muito preocupados com a proibição do bispo de Mariana, mas não sossegaram; solicitaram diretamente ao Rei a permissão de celebrar missas na capela da Serra, sendo atendidos. Germana foi novamente levada ao alto da Serra; de tempo em tempo seu diretor ali ia dizer missa, e na ocasião de minha viagem a frequência de peregrinos e curiosos renova-se semanalmente.

Pouco tempo antes da minha estada ali, um novo prodígio começara a se manifestar na pretendida santa. Todas as terças-feiras ela experimentava um êxtase de algumas horas; seus braços deixavam a posição natural e, enquanto durasse o êxtase, ficavam cruzados atrás das costas da doente. No correr da conversa que tive com o seu confessor, disse-me ele que durante algum tempo não soubera como explicar esse fenômeno; mas havia terminado por lembrar-se que a terça-feira era o dia em que se costumava oferecer à meditação dos devotos os sofrimentos de Jesus crucificado.

Quando cheguei pela primeira vez ao alto da Serra, fui recebido pelo diretor da enferma. Haviam-me gabado muito o desinteresse e a caridade desse eclesiástico. Conversamos durante muito tempo; não me pareceu desprovido de instrução. Falou-me de sua penitência sem nenhum entusiasmo. Desejava, segundo me disse, que os homens competentes estudassem o estado de Germana, e a única censura que fez ao dr. Gomide foi de ter escrito seu opúsculo sem se ter dado o trabalho de ver vir a sua enferma. Se o que esse padre me relatou sobre sua ascendência sobre Germana não foi exagerado, os partidários do magnetismo animal daí tirariam provavelmente grande partido em apoio de sua doutrina. Afirmou-me, com efeito, que em meio às mais terríveis convulsões era bastante que ele tocasse na doente para torná-la calma. Quando Germana se achava em seus êxtases periódicos, seus membros adquiriam tal rigidez que seria mais fácil quebrá-los que dobrá-los; mas se se pode acreditar no testemunho de seu confessor, por pouco que tocasse o braço ou a mão da doente ele lhes dava a posição que quisesse. O que é certo é que tendo o confessor de Germana lhe ordenado que comungasse em um dos seus dias de êxtase, ela se levantara, num movimento convulso, do leito que havia sido levada à igreja; ajoelhada, mas com os braços 
sempre cruzados, ela recebeu a santa hóstia, e, desde essa ocasião sempre repetiu a comunhão no meio de seus êxtases. Aliás, o diretor de Germana falava sempre com muita simplicidade do seu domínio sobre a pretensa santa; ele o atribuía à docilidade da enferma e seu respeito pelo caráter sacerdotal, acrescentando que qualquer outro eclesiástico poderia conseguir os mesmos resultados. Esse homem dizia-me com aquela confiança que os magnetizados exigem de seus adeptos: a obediência dessa pobre moça é tal que se eu lhe ordenar que passe uma semana inteira sem se alimentar, ela não hesitará em atender-me, e nada sofrerá; mas, acrescentava, receio ofender a Deus com uma experiência dessas.

Pedi para ver Germana e fui levado ao pequeno quarto onde ela ficava permanentemente deitada. Percebi seu rosto sob um grande lenço que se prolongava adiante de sua testa; pareceu-me não ter mais de 34 anos, idade que efetivamente lhe atribuíam. Sua fisionomia era doce e agradável, mas indicava grande magreza e debilidade extrema. Perguntei-lhe como se achava e, com voz quase sumida, respondeu-me que se achava melhor do que merecia. Tomei-lhe o pulso e surpreendi-me de achá-lo muito acelerado.

Voltando na sexta-feira ao alto da montanha, fui, pela segunda vez, ao quarto de Germana. Ela se achava sobre seu leito, deitada de costas, com a cabeça envolta em um lenço. Seus braços estavam em cruz; um deles detido pela parede, não tivera a liberdade de estender-se completamente; o outro estendia-se para fora da cama e estava apoiado sobre um tamborete. A doente tinha as mãos extremamente frias; o polegar e o indicador estavam esticados, os outros dedos fechados, os joelhos dobrados e os pés colocados um sobre o outro. Nessa posição Germana conservava a mais perfeita imobilidade; seu pulso era apenas perceptível e poder-se-ia acreditá-la morta se seu peito, devido à respiração, não agitasse ligeiramente a coberta. Experimentei várias vezes dobrar seus braços, inutilmente; a rigidez dos músculos aumentava em consequência dos meus esforços e convenci-me de que se insistisse poderia prejudicar a doente. Na verdade, fechei suas mãos várias vezes, mas no momento que largava seus dedos eles retornavam à posição anterior. A irmã de Germana que ordinariamente cuidava dela, e que se achava presente na ocasião de minha visita, disse-me que essa pobre moça não se apresentava sempre tão calma durante seus êxtases, como nesse dia; que na verdade seus pés e seus braços ficavam constantemente imóveis, mas que ela frequentemente gemia e suspirava, que sua cabeça se agitava sobre o travesseiro, e que movimentos convulsivos se manifestavam principalmente aí pelas três horas, momento em que Jesus Cristo expirara.

Antes de subir à Serra para ver Germana durante seus êxtases, pretendera experimentar nela a ação do magnetismo animal; mas a presença de várias testemunhas impediu-me de fazê-lo com regularidade. Entretanto, sob pretexto de tomar o pulso da doente, coloquei minha mão esquerda sobre a sua e pus-me na 
disposição de espírito exigida pelos magnetizadores; nenhum resultado obtive, mas, para ser exato, devo confessar que minha atenção era desviada sem cessar pela presença de testemunhas e por suas conversas.

Deixei a Serra da Piedade no dia seguinte àquele em que vira Germana em êxtase. Distanciando-me da região em que ela residia, não mais ouvi falar a seu respeito, e ignoro qual tenha sido o fim dessa infeliz.*

* Os senhores Spix e Martius, que passaram por Sabará algum tempo depois, visitaram também a Serra da Piedade, a ela se referindo em poucas palavras. Dizem eles que essa montanha havia sido, durante muitos anos, o asilo de uma mulher portadora de ataque de catalepsia, e que a olhavam como santa; mas eles não a viram porque recentemente as autoridades haviam julgado conveniente afastá-la da Serra. Depois que tudo estava escrito tive notícia que a morte havia posto termo aos sofrimentos de Germana. (Nota de Saint-Hilaire)

\section{Auguste de Saint-Hilaire (1779-1853)}

Importante botânico e explorador francês, publicou várias obras sobre o Brasil, onde esteve em expedições científicas entre os anos de 1816 e 1822. Sua visita à Serra da Piedade (MG) ocorreu em 1818 e foi descrita em Voyage dans le district des diamans et sur le litoral du Brésil (1833). 